\title{
Challenges and strategies to improve the availability and geographic accessibility of physicians in Portugal
}

\author{
Ana Paula Cavalcante de Oliveira*, Gilles Dussault and Isabel Craveiro
}

\begin{abstract}
Background: Shortages of physicians in remote, rural and other underserved areas and lack of general practitioners limit access to health services. The aims of this article are to identify the challenges faced by policy and decisionmakers in Portugal to guarantee the availability and geographic accessibility to physicians in the National Health Service and to describe and analyse their causes, the strategies to tackle them and their results. We also raise the issue of whether research evidence was used or not in the process of policy development.
\end{abstract}

Methods: We analysed policy and technical documents, peer-reviewed papers and newspaper articles from 1995 to 2015 through a structured search of government websites, Portuguese online newspapers and PubMed and Virtual Health Library (Biblioteca Virtual em Saúde (BVS)) databases; key informants were consulted to validate and complement the documentary search.

Results: The challenges faced by decision-makers to ensure access to physicians were identified as a forecasted shortage of physicians, geographical imbalances and maldistribution of physicians by level of care. To date, no human resources for health policy has been formulated, in spite of most documents reviewed stating that it is needed. On the other hand, various isolated and ad hoc strategies have been adopted, such as incentives to choose family health as a specialty or to work in an underserved region and recruitment of foreign physicians through bilateral agreements.

Conclusions: Health workforce research in Portugal is scarce, and therefore, policy decisions regarding the availability and accessibility of physicians are not based on evidence. The policy interventions described in this paper should be evaluated, which would be a good starting point to inform health workforce policy development.

Keywords: Health labour market, Shortage of physicians, Geographical imbalances, Level of care maldistribution, Health workforce interventions

\section{Background}

Imbalances in the geographical distribution of qualified Human Resources for Health (HRH) in rural or poor areas are observed in almost all countries in the world [1-7], including Portugal in spite of its small dimension [8-26]. Their impact is that access to health services is limited for segments of the population whose health needs

* Correspondence: paula.cavalcante@ihmt.unl.pt

Global Health and Tropical Medicine, Instituto de Higiene e Medicina

Tropical, Universidade Nova de Lisboa, Rua da Junqueira, 100, 1349-008

Lisbon, Portugal may not be addressed adequately in a timely manner. The availability and accessibility of qualified health workers determines which services, and in which quantity, will be available to a population $[1,2,5,27]$. In the context of the commitment of the member states of the United Nations Assembly to universal health coverage and to achieving the Sustainable Development Goals, this problem is a major challenge for policy-makers. Research on health workforce topics have been developed in the last 10 years almost exponentially, and evidence on what works and what does not work to respond to this challenge is available. A relevant research question is whether and how research results inform policy-making. 
The aims of this article are to identify the challenges faced by policy and decision-makers in Portugal at the national level to guarantee the availability and geographic accessibility of physicians in the National Health Service (NHS) and to analyse their causes, the strategies to tackle them and their results. We also raise the issue of whether research evidence was (not) used in the process of policy development.

We first describe the data collection and analysis process and follow by describing how the three challenges of shortage, geographical and level of care imbalances were identified and analysed. A presentation of the various interventions developed by policy-makers to address these challenges follows. We then discuss the factors that influenced policy-making in relation to health workforce issues.

\section{Methods}

This work is part of a holistic multiple-case study that includes three phases of data collecting. It aims to understand the process by which HRH policies addressing the geographical distribution of physicians are (not) informed by scientific evidence. This article reports the first and second phase of the case study, in which we analyse policy and technical documents, peer-reviewed articles and newspaper articles with the purpose of understanding the policy-making process in relation to the health labour market in Portugal. We conducted a structured search in PubMed and the Virtual Health Library (Biblioteca Virtual em Saúde (BVS)), in government and other relevant websites and in newspapers available online. In parallel, we consulted six informants (a researcher, three professionals from the Ministry of Health $(\mathrm{MoH})$ and two from the NHS) to validate our data collection strategy and eventually give us access to unpublished documents. The search strategy is described in Additional file 1: Table S1. Selected documents were classified as (I) official documents of the Portuguese government, such as National Health Plans, relevant legislation, technical and policy analysis reports and policy statements; (II) scientific research documents including peer-reviewed articles and research reports; and (III) newspaper articles.

We used an adaptation of the health labour market and policy lever framework proposed by Sousa et al. (Fig. 1) [28], to improve the understanding of the dynamics of the health labour market and to identify relevant policy options [29]. The quantity of health workers that employers are willing to hire and the demand for health services by individuals, provider organizations or health planners define the demand for health workers [30, 31]. The number of health workers required to produce a certain set of health care services depends on a number of factors such as their competencies, available technology and productivity [29]. The number of health workers

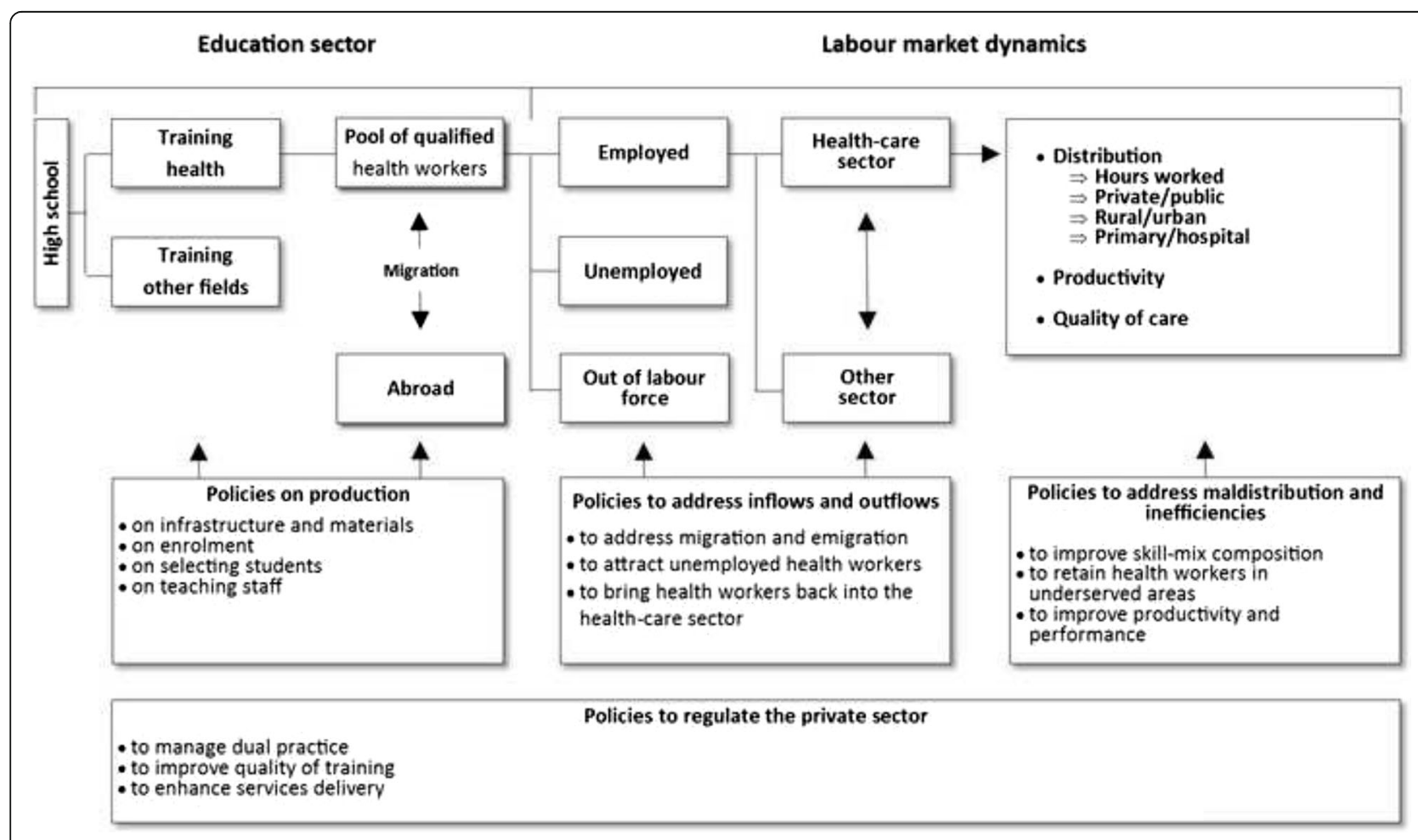

Fig. 1 Health labour market and policy lever framework. Source: Adapted from Sousa et al. [28] 
employed or willing to work in the health care sector constitutes the supply. It varies principally according to inflows from the education pipeline and from immigration, and according to outflows through emigration, career breaks, retirement and other forms of attrition [31]. Policy interventions can cover four areas according to their purpose: production, inflows and outflows, the regulation of the private sector and imbalances and inefficiencies in the distribution and utilization of health workers [28].

Health policy is "the process by which a problem is conceptualized, solutions and alternatives are formulated, decisions are taken, policy instruments are selected and programmes and strategies are implemented" [32] in order to respond to a social problem. Policy defines what decision-makers intend to do, and strategies specify how they plan to do it.

Data extraction was made by sub-categories using codes to answer the following questions:

1. What are the challenges faced by decision-makers at the national level in Portugal to ensure access to physicians?

2. What are the causes/determinants of these challenges?

3. What were the strategies implemented to address these issues?

4. What were the results of these strategies?

The program MaxQDA 2012 was used to facilitate the categorization and Mendeley to organize references.

\section{Results}

The BVS and PubMed search (April 2015) identified 909 and 930 documents, respectively, for a total of 1426 documents after the exclusion of duplicates. The application of the inclusion criteria reduced the list of selected documents for full reading to 47 , and six studies identified by key informants and other sources were added; Additional file 2: Figure S2 shows the process of selection of peer-reviewed article search. The website search identified 49 documents, of which 16 are policy documents and 33 are technical reports. The search of online newspapers identified 1454 potentially relevant articles, and 94 were selected for analysis. The full list of 155 analysed documents is available on request.

Most the articles identified in this documentary search (nine out of 12 documents) report that the authors did not have access to external financial support or did not mention any.

\section{Geographical access to physicians in the Portuguese National Health Service}

The challenges faced by decision-makers to ensure access to physicians at the national level were identified as (a) a forecasted shortage of physicians, (b) geographical imbalances and (c) maldistribution by level of care.

\section{Shortage of physicians?}

Although the number of physicians in Portugal per 1000 habitants has been above the European Union (EU) 27 countries' average between 1995 and 2013 [33], a shortage of physicians has been forecasted, particularly of general practitioners/family physicians (GPs) and of public health physicians in three scientific research documents, three political documents and one policy analysis document [13, 14, 19, 21, 34-36]. This was attributed to the low numerus clausus policy limiting entry in medical schools between 1979 to 2000, combined with the planned retirement of large numbers of physicians in the coming years $[14,19,21,25,37-39]$. In 1979, the numerus clausus was 805 ; in 1985 , it dropped to 272 ; and in 2001, it was increased to 945 [40].

No analysis other than forecasting the numbers of future graduates and future retirees has been found. There is no monitoring of outflows to the private sector, to other sectors other than health or to other countries; dual practice is not monitored either [12, 23, 39, 41, 42]. Emigration flows are estimated by proxy indicators such as cancellation or suspension of registration and requests of Certificates of Good Standing [43, 44], which rose from 191 in 2009 to 650 requests in 2012 only in the South Regional Session of the Portuguese Medical Council [43]. In 2014, the total number of requests was approximately 1100 for the whole country [45], and between January and May 2016, there were another 226 requests [46].

\section{Geographical imbalances}

The geographical maldistribution of physicians is acknowledged in Portugal; it is discussed in six scientific research documents, four political documents and nine policy analysis documents [8-26]. The distribution of physicians favours the three main urban areas of Oporto, Coimbra and Lisbon $[8,11,22,47,48]$ (Fig. 2) where the most advanced technology and the oldest medical schools and teaching hospitals are found [10, 48]. In 2011, the Northern and the Lisbon/Vale do Tejo (LVT) regions, where $65 \%$ of the population resides, had $74 \%$ of NHS physicians; the Central region had $18 \%$, Alentejo $4 \%$ and Algarve 4\%, whereas they had 23, 7.5 and $4.5 \%$ of the population respectively $[47,49]$. Portuguese private practitioners also tend to concentrate in the richer urban areas, as is the case in most Organisation for Economic Co-operation and Development (OECD) countries [50].

The maldistribution has been attributed to the lower supply of NHS beds and to the population's lower purchasing power $[8,10]$ in disadvantaged regions. Another factor is the possibility of multiple employment in urban 


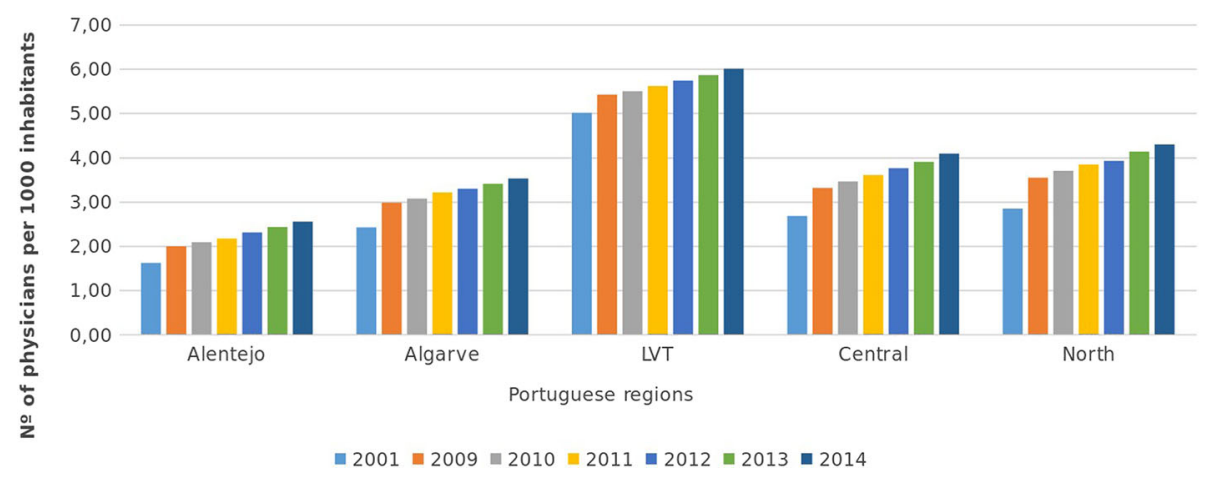

Fig. 2 Number of physicians per 1000 inhabitants from 2009 to 2014 per region. Source: Fundação Francisco Manuel dos Santos [47]

areas where the private sector offers additional remuneration opportunities [10].

\section{Maldistribution by level of care}

Another challenge identified in the documentation under review is the imbalanced distribution of physicians between primary care (PC) and hospital services; it is discussed in five scientific research documents and 11 policy analysis documents [11-16, 24, 34, 37, 42, 48, 51-55]; this is in spite of a stated policy to promote Family Health Care $[11,52,54,56]$, which includes the creation of Family Health Units [57, 58] consisting in multi-professional units which have organizational, technical and functional autonomy and that provide personalized health care to a given population $[59,60]$. The first ones were implemented in 2007, and in late 2016, there are 459 covering $53 \%$ of the population.

The reason for the maldistribution was attributed to the low prestige of $\mathrm{PC}$, to the lack of planning and to the limited number of internship places in family medicine as training capacity had not been developed in health centres $[14,34,37,52]$. The problem is compounded by the ageing of the medical profession specially affecting GPs [42, 61-63], 75\% of whom were above 50 years of age in 2011 [49], and by a wave of early retirements provoked by the austerity measures implemented after 2011 in the NHS [37, 49, 64].

\section{Strategies to address health workforce imbalances}

A first attempt to define a strategy for the development of the health workforce was the publication, in 2001, of a "Strategic Plan to Education and Training in The Health Areas" $[11,19,65]$. It drew the attention to geographical and level of care imbalances and predicted a shortage of physicians in the coming years. In the context of political instability prevalent at that time, there was no follow-up [11].

The National Health Plan 2004-2010 [22, 66] represented a second planning effort. It raised the issue of skill mix and new competencies needs, but did not go "much beyond a call for a more explicit strategy" [11]. In 2012, the National Health Plan 2012-2016 [67], following recommendations of the World Health Organization $[25,42]$, included the objective of designing and implementing a HRH policy [23]. However, the targets set in the Plan were restricted to numbers of physicians per inhabitant, from 3.83 physicians per 1000 habitants in 2009 to 4.51 in 2016 [23, 68].

To date, no HRH policy has been formulated [23, 25, 42], in spite of numerous policy documents and reports stating that it is needed. On the other hand, various isolated and ad hoc strategies have been adopted.

Strategies to address shortage included an increase in the numerus clausus, the opening of new medical schools and programmes, an increase of residency places and the re-hiring physicians who had retired from the NHS. This last strategy was also intended to reduce the level of care maldistribution of physicians.

Since 1999, there has been a gradual rise in the numerus clausus; in 2010, it was 2.5 times higher than 15 years before [69], whereas population growth during that period was 3.5\% [47]. Until 1999, Portugal had five medical schools, two in Lisbon, two in Oporto and one in Coimbra offering a total of 566 places [14, 70]. Two new medical programmes were opened in 2001 in universities of the interior of the country $[9,14]$. Additionally, a course exclusively for students holding a bachelor's degree opened in 2009 in Algarve to attract young professionals to the south of the country [70]. In 2004/2005, basic courses were created in Azores and Madeira Islands; students complete the first 3 years of medical education there and the remaining years at the University of Coimbra [10, 70].

There was also an increase in the number of residency slots for specialization, after the compulsory postgraduation of general internship that includes a total of 6 months involving general practice and public health and a year of hospital-based training. It is followed by a 
period of 4 to 6 years of training for a medical specialty $[14,37,69]$. There are three medical career streams: hospital-based practice (45 specialties), public health and general practice $[10,71]$. The $\mathrm{MoH}$ defines the number of residency places in consultation with the Medical Council, depending on the available training capacity in recognized provider organizations $[40,69]$. The number of residency places grew from 894 in 2006 [69] to 1569 in 2015 [72].

The re-hiring of retirees for a period of 3 years was authorized in June 2010 [35]. It aimed to overcome the shortage of physicians [37, 73, 74], particularly of GPs [35, 73]. In 2013, this strategy was extended for another 3 years $[21,74]$. It is applicable to any retired physician, including those who anticipated their retirement. The benefits include the accumulation of the pension with a third of the remuneration according to contracted hours [73].

We identified four strategies addressing the geographical maldistribution of physicians: reserved vacancies, the "partial mobility of professionals", financial and nonfinancial incentives during a 5-year period to work in an underserved area and four bilateral agreements to recruit physicians from other countries to work in PC in underserved areas.

In 1975, a strategy referred to as the "Medical Service in Peripheries" introduced a 1-year compulsory service outside urban areas $[75,76]$. This was implemented until 1982. In 2009, financial incentives were introduced for resident physicians who commit to work in an underserved area or specialty after graduation during a period equal to their specialist medical training programme; this policy was referred to as "reserved vacancies" [40, 77, 78]. It consisted in a monthly residency grant of $€ 750$, paid by the municipality where the physician committed to work [79]. In case of failure to fulfil the obligation, the resident had to repay the grant [77]. No evaluation of this measure has been identified. This strategy is now restricted to the Azores and Madeira Islands.

The "partial mobility of physicians" regulation, approved in 1998 and updated in 2015 [80], is a special arrangement that provides for a daily allowance and transport subsidy ( $€ 200$ per day) accessible to physicians who work part-time in two or more public services more than $60 \mathrm{~km}$ apart; it is particularly used in the region of Algarve, which experiences important seasonal variations in its resident population [73, 80].

In 2015, a new law created a set of financial and nonfinancial incentives to attract and retain physicians in poor and underserved areas [20]. These incentives target physicians working in a NHS establishment in an underserved area [20]. Under this scheme, physicians who accept a 5-year contract receive an additional $€ 1000$ for the first 6 months, then $€ 500$ for the next 6 months and $€ 250$ per month for the remaining 4 years [20]. Additional incentives are available, such as child's school transfer guarantee, support to spouse employment and an extra 2 days of annual leave [20,73]. Penalties and reimbursement are imposed in case of non-compliance [20].

Since 2008, the $\mathrm{MoH}$ has used an "emergency measure" in the form of the recruitment of foreign physicians through bilateral agreements with Latin American countries [10, 23, 25, 57, 81]. This option was chosen because attracting workers from other European countries proved difficult as Portugal could not offer conditions competing with those offered by countries like Germany or England [82]. The first bilateral agreement was signed with the government of Uruguay in 2008; 15 physicians came to work for the National Institute of Medical Emergencies [83-85]. In 2009, another one was signed with Cuba, and 44 physicians arrived to work in five health centres in Algarve, nine in Alentejo and one in LVT [86-88]. They returned to Cuba in 2012 and were replaced by another cohort [89, 90]. Another replacement took place in 2014 [91-93]. In 2011, bilateral agreements with Colombia and Costa Rica brought 82 and nine physicians, respectively, to health centres in the LVT and Central regions [85, 94-97]. Foreign medical degrees were validated by the Faculty of Medicine of Porto, and registration with the Medical Council followed [83, 95, 98, 99]. Prior to arrival, the physicians attended a Portuguese language course [83, 95, 100]. They also had a 2-week period for adaptation/integration into the services [95]. There has been no evaluation of the efficiency or effectiveness of these recruitments. A study that assessed the foreign physicians' cultural competencies concluded that these health professionals performed in a culturally competent manner and contributed positively to improving access to health services [81].

Four strategies aimed at changing the distribution of physicians by level of care. First, the PC reform was designed as a strategy to increase the recognition of GPs' career and to improve accessibility to primary level services. Second, in 2007, a quota of $25 \%$ of residency places for GPs was established [37, 40, 101]. Over the years, this has contributed to augmenting the number of GPs, but it has not been sufficient to extend PC coverage to the whole population $[54,102,103]$. In $2015,12 \%$ of the population was still without access to a GP, ranging from 3.3\% in the North to $25.8 \%$ in Algarve [104]. Third, the bilateral agreements to recruit foreign physicians aimed at addressing, at the same time, geographical and level of care maldistribution as they concerned only family practitioners, and finally, there was the rehiring of retired physicians which focused on family physicians. The interventions to address supply, geographic 
and level of care maldistribution by area of political intervention are presented in Additional file 3: Table S2.

\section{Discussion}

In Portugal, like in any country with a national health system offering universal coverage, policy and decisionmakers are challenged to ensure the availability and accessibility of physicians in all geographical areas, at the most appropriate level of care.

The "shortage" of physicians is not related to their insufficient total number, as shown by ratios to population above the EU average, but to the unwillingness of these professionals to work in certain zones of the country. The lack of physicians at the PC level is better explained by the insufficient number of residency places and the age structure of GPs than by the unavailability of physicians. Even though this has been documented and highlighted by many observers, there is still a lack of evidence-informed policies to address these problems.

Workforce policies limited to training more physicians are not sufficient to address shortages as they ignore the dynamics of health labour market [28]. For instance, whether market conditions are adequate or not to attract and absorb the newly qualified professionals is critical to the decisions by future physicians as to which specialty to choose, where to work and even to stay in the country [28]. The absence of data on future graduates' expectations and intentions as to their professional life makes it difficult to adjust policies of attraction and retention to ensure that population needs will be met. Without a valid diagnosis of the current situation and a comprehensive and up-to-date database, policies risk to be developed in an improvised rather than in an informed manner.

The implementation by the Portuguese government of the various health workforce interventions mentioned here has generated debate. Medical organizations "have unsuccessfully opposed" those targeting geographical imbalances using the argument that the lack of incentives for physicians to work in underserved areas was the main problem, not their scarcity [12]. There is a paradox in having difficulty in recruiting physicians in some regions and in PC and having hundreds of Portuguese physicians migrating to other European countries as well as to Australia, the Gulf States and even Brazil $[23,40]$. There is also a paradox in recruiting from Latin America, while hundreds of young Portuguese study medicine in countries such as Hungary, Slovakia, France, Spain and the Czech Republic and return to Portugal at the time of specialization [41]. Further analysis is needed of the factors that influence the choice of physicians to migrate as well as of those which bring them to avoid work in underserved areas. Qualitative studies and discrete choice experiments should be prioritized as they help identify and understand the preferences of future professionals and of those already in practice $[105,106]$.

The same reasoning applies to how to address the imbalanced distribution between PC and hospital services. The reasons for this maldistribution are considered to be the low prestige of $\mathrm{PC}$, the lack of planning and coordination of training and the limited number of internship places in family medicine. Only the last one was addressed, in a partial manner, by raising the quota of residency places in family medicine. The effects of this measure and the bilateral agreements to recruit abroad and the re-hiring of retired GPs have yet to be properly assessed.

Interventions to tackle the challenges reviewed here have been implemented in an isolated manner. Evidence on the subject indicates that combinations of actions are more effective than isolated ones [4]. Also, all these interventions focused on the provision of services by the public sector, whereas the private sector occupies an important space in the health labour market in Portugal and influences physicians' career choices.

There is a diversity of theories and analytical frameworks seeking to explain a policy process. The most common approach disaggregates the process into a number of functional steps [107]. An example is the policy cycle, which is typically divided into four stages: agenda setting, formulation policy development, implementation and evaluation [108-110]. The policy process is influenced by different factors [111, 112], and this is where scientific evidence can play a significant role. At each stage of the policy cycle, there is a corresponding stage of research that can serve to inform the policy process $[113,114]$. For example, when a problem is not on the agenda and needs to be brought to the attention of policy-makers, research that documents it and identifies its causes and the need for action is useful. Research can also contribute to identifying policy options and their relative capacity to address the problem as well as the risks involved in their implementation.

Furthermost, research on health workforce in general and on physicians in particular is limited in Portugal. Demand-on the part of policy and decision-makers- is weak as illustrated by the low priority which the main source of financial support for research in Portugal, the Foundation for Science and Technology, gives to health service research, let alone to research on health workforce issues [23].

This study based on documentary analysis has limitations because we cannot pretend to have a comprehensive perspective of the Portuguese health policy context only on the basis of written sources. This is why an additional phase of our research, consisting in interviews 
with key policy and decision-makers and researchers, is in development.

\section{Conclusions}

In this paper, we reported that policy and decisionmakers face challenges to assure geographical access to physicians in the Portuguese NHS, because of geographical and level of care imbalances, and that strategies to tackle these challenges are sparse and not evaluated. Furthermore, research in human resources and distribution of physicians, in particular, is limited in Portugal.

More investment is therefore needed in research to analyse the causes of maldistribution in Portugal, particularly on individual and professional factors that influence the choice of a location of practice and on interventions to mitigate the problem. This would provide the basis for comprehensive evidence-based health workforce policy development. Also, it is necessary to have tools in place to help identify, analyse and evaluate research conducted in other contexts and adapt its results to the Portuguese context and needs.

\section{Additional files}

Additional file 1: Table S1. Search strategy [47, 104, 115-122].

(DOCX $18 \mathrm{~kb}$ )

Additional file 2: Figure S2. Flowchart of peer-reviewed articles search results (BVS and PubMed). (JPG $145 \mathrm{~kb}$ )

Additional file 3: Table S2. Interventions to address supply, geographic and level of care maldistribution by area of political intervention $[2,5,123]$. (DOCX $18 \mathrm{~kb})$

\section{Acknowledgements}

This paper is part of a research project supported by CNPq Brazil. The authors would like to thank Prof. John N. Lavis for the valuable comments on the method and Claudia Conceição, Carlota Pacheco Vieira, Maria A Cortes, Marta Temido, Ines Matos and Tiago Costa for their help in the process of identifying the strategies and providing documents. Also, the authors thank Mariana Gabriel and Pedro Leite Alves for valuable comments and technical support.

\section{Funding}

APCO is a National Council for Scientific and Technological Development (CNPq), Brazil, grant holder (no 201988/2012-7) and IC is a National Funding Agency for Science (FCT), Portugal, grant holder (SFRH/BPD/80201/2011).

\section{Availability of data and materials}

Not applicable.

\section{Authors' contributions}

APCO conceived the study, collected and analysed the data and participated in all stages of the preparation of the article; GD and IC contributed to all stages of the preparation of the article. All authors read and approved the final manuscript.

\section{Competing interests}

The authors declare that they have no competing interests.

\section{Consent for publication}

Not applicable.
Ethics approval and consent to participate

Not applicable.

Received: 3 August 2016 Accepted: 17 February 2017

Published online: 23 March 2017

\section{References}

1. Dussault G, Dubois C-A. Human resources for health policies: a critical component in health policies. Hum Resour Health. 2003;1:1.

2. Dussault G, Franceschini MC. Not enough there, too many here: understanding geographical imbalances in the distribution of the health workforce. Hum Resour Health. 2006;4:12. doi:10.1186/1478-4491-4-12.

3. Dussault G, Fronteira I, Prytherch H, Dal Poz MR, Ngoma D, Lunguzi J. Scaling up the stock of health workers: a review. Geneva, Switzerland: International Centre for Human Resources in Nursing (ICHRN); 2009.

4. Kroezen M, Dussault G, Craveiro I, Dieleman M, Jansen C, Buchan J, et al. Recruitment and retention of health professionals across Europe: a literature review and multiple case study research. Health Policy Elsevier Ireland Ltd. 2015;119:1517-28. http://dx.doi.org/10.1016/j.healthpol.2015.08.003

5. WHO. Increasing access to health workers in remote and rural areas through improved retention. Geneva, Switzerland: World Health Organization; 2010. Available from: http://www.who.int/hrh/retention/ guidelines/en/. Accessed July 2016.

6. Campos FE, Machado HH, Girardi SNN. The retention of health professionals in high need areas. Divulg Em Saúde Para Debate. 2009;44:13-24.

7. Chen L, Evans T, Anand S, Boufford Jl, Brown H, Chowdhury M, et al. Human resources for health: overcoming the crisis. Lancet. 2004;364:1984-90.

8. Correia I, Veiga P. Geographic distribution of physicians in Portugal. Eur J Health Econ Germany. 2010;11:383-93. doi:10.1007/s10198-009-0208-8.

9. Oliveira M, Magone J, Pereira J. Nondecision making and inertia in Portuguese health policy. J Heal Polit Policy Law. 2005;30:211-30.

10. Russo G, Ferrinho P, de Sousa B, Conceicao C. What influences national and foreign physicians' geographic distribution? An analysis of medical doctors' residence location in Portugal. Hum Resour Health England. 2012;10:12. doi:10.1186/1478-4491-10-12

11. Dussault G, Ferrinho P. A health workforce strategy for Portugal. Cah Sociol Demogr Med France. 2007:47:235-40.

12. Ribeiro JS, Conceição C, Pereira J, Leone C, Mendonça P, Temido M, et al. Health professionals moving to... from Portugal. Health Policy. 2014; 114:97-108. http://dx.doi.org/10.1016/j.healthpol.2013.05.009.

13. Conceicao C, Lima C, Ferrinho P. Reforming the Portuguese health services system: key human resources for health issues. Cah Sociol Demogr Med France. 2007:47:241-57.

14. Barros PP, Simões JDA. Health systems in transition: Portugal: health system review. Allin S, Mossialos E, editors. Copenhagen: World Health Organization; 2007.

15. OPSS. Relatório de Primavera 2001: conhecer os caminhos da saúde. Lisboa, Portugal: Escola Nacional de Saúde Pública; 2001.

16. OPSS. Relatório de primavera 2002: o estado da saúde e a saúde do estado. Lisboa, Portugal: Escola Nacional de Saúde Pública; 2002.

17. OPSS. Relatório de primavera 2008: sistema de saúde português: riscos e incertezas. Coimbra, Portugal: Centro de Estudos e Investigação em Saúde da Universidade de Coimbra; 2008

18. OPSS. Relatório de primavera 2015: acesso aos cuidados de saúde. um direito em risco? Observatório Português dos Sistemas de Saúde - OPSS; 2015

19. Grupo de Missão. Plano estratégico para a formação nas áreas da saúde. Lisboa: Grupo de Missão; 2001

20. Diário da República n. 108 1. Série. Decreto-Lei n. ${ }^{\circ}$ 101/2015. Lisboa, Portugal: Ministério da Saúde; 2015. p. 3604-5.

21. Diário da República n. ${ }^{\circ} 137$ 1. ${ }^{\text {a }}$ Série. Decreto-Lei n. ${ }^{\circ}$ 94/2013. Lisboa, Portugal: Ministério da Saúde; 2013. p. 4184-5.

22. Portugal. Plano nacional de saúde 2004-2010: Vol. II—Orientações estratégicas. Ministério. Design. Lisboa, Portugal: Direcção-Geral da Saúde; 2004.

23. Dussault G. Plano nacional de saúde 2012-2016: roteiro de intervenção em recursos humanos em saúde (RHS). Lisboa: Plano Nacional de Saúde 20122016 e Direção-Geral da Saúde; 2014

24. Santana P, Couceiro L, Alves I, Nogueira H, Costa C, Santos R. Caracterização demográfica dos profissionais de saúde no serviço nacional de saúde português. Volume V. Sumário executivo. 2007. 
25. WHO. WHO evaluation of the national health plan of Portugal (2004-2010) Copenhagen: World Health Organization; 2010.

26. OPSS. Relatório de Primavera 2014: Saúde Síndroma de Negação. Lopes M, Mendes F, Escoval A, editors. Lisboa: Observatório Português dos Sistemas de Saúde - OPSS; 2014.

27. Zurn P, Dal Poz MR, Stilwell B, Adams O. Imbalance in the health workforce. Hum Resour Health. 2004;2:13.

28. Sousa A, Scheffler RM, Nyoni J, Boerma T. A comprehensive health labour market framework for universal health coverage. Bull World Health Organ. 2013;91:892-4. http://dx.doi.org/10.2471/BLT.13.118927.

29. Vujicic M, Zurn P. The dynamics of the health labour market. Int J Health Plann Manage. 2006;21:101-15. doi:10.1002/hpm.834.

30. Dussault G, Vujicic M. Demand and supply of human resources for health In: Heggenhougen K, Quah S, editors. Int. Encycl. public Heal. Academic P. San Diego: Elsevier; 2008. p. 77-84.

31. WHO. Understanding health labour markets in the Western Pacific Region. Geneva: World Health Organization; 2014.

32. Jansen MW, van Oers HA, Kok G, de Vries NK. Public health: disconnections between policy, practice and research. Health Res Policy Syst BioMed Central Ltd. 2010;8:37. doi:10.1186/1478-4505-8-37.

33. OECD. Health at a glance 2015: OECD indicators [Internet]. Paris: OECD Publishing; 2015. Available from: http://www.oecd-library.org/social-issuesmigration-health/health-at-a-glance_19991312 [last accessed in Jul 2016].

34. Biscaia A, Conceição C, Martins J, Ferrinho P. Policy and management of human resources in the health care system of Portugal. Cah Sociol Demogr Med. 2003;43:379-96.

35. Diário da República n. ${ }^{\circ} 1401^{\text {a }}$ Série. Decreto-Lei n. ${ }^{\circ}$ 89/2010. Lisboa: Ministério da Saúde; 2010. p. 2769-71.

36. OPSS. Relatório de Primavera 2013: duas faces da saúde. Lisboa: Observatório Português dos Sistemas de Saúde - OPSS; 2013.

37. Barros PP, Machado SR, Simoes I de A. Health systems in transition: Portugal: health system review. Health Sys. Health Syst. Transit. Denmark; 2011.

38. OPSS. Relatório de Primavera 2012: Crise \& Saúde: um paíse em sofrimento. Lisboa: Observatório Português dos Sistemas de Saúde - OPSS; 2012.

39. Leone C, Conceicao C, Dussault G. Trends of cross-border mobility of physicians and nurses between Portugal and Spain. Hum Resour Health England. 2013;11:36. doi:10.1186/1478-4491-11-36.

40. Portugal. Revisão do regime de internato médico: relatório final. 2012. Available from:http://www2.portaldasaude.pt/NR/rdonlyres/606051AC-82FB46F7-8CBB-A97B5056E80B/0/RevisaolntMedicoRelFinalMaio2012.pdf . Accessed May 2016.

41. Conceição C, Ribeiro JS, Pereira J, Dussault G. Mobility of health professional: national report: Portugal macro level research. Lisboa: WIAD; 2009.

42. WHO. Portugal health system: performance assessment. Copenhagen: World Health Organization; 2010.

43. Conselho Nacional Executivo da Ordem dos Médicos. Médicos portugueses no estrangeiro: uma realidade multifacetada. Rev. Ordem dos Médicos №152. Lisboa: Ordem dos Médicos; 2014. p. 18-30.

44. WHO. Case study: the impact of the financial crisis on the health system and health in Portugal. Copenhagen: World Health Organization; 2014

45. Netfarma. Netfarma portal dos profissionais do setor farmacéutico: noticias/ saúde: quase 400 médicos emigraram no ano passado. 2015 Available from: http://www.netfarma.pt/noticia/medicos-emigracao-certificados-om . Accessed July 2016.

46. Jornal de Notícias. Nacional: em cinco meses emigraram 184 médicos à procura de melhores salários. 2016. Available from: http://www.jn.pt/ nacional/interior/em-cinco-meses-emigraram-184-medicos-a-procura-demelhores-salarios-5242469.html . Accessed July 2016.

47. Fundação Francisco Manuel dos Santos. PORDATA: base de dados Portugal contemporâneo. Available from: http://www.pordata.pt/Home [last accessed in Jul 2016].

48. Biscaia A, Martins J, Carrolo M. The state of the health workforce in Portugal. Cah Sociol Demogr Med France. 2007;47:259-73.

49. Santana P, Peixoto H, Loureiro A, Costa C, Nunes C, Duarte N. Estudo de evolução prospectiva de médicos no sistema nacional de saúde: relatório final. Coimbra: Universidade de Coimbra; 2013

50. OECD. Health workforce policies in OECD countries: right jobs, right skills, right places. Paris; 2016. http://dx.doi.org/10.1787/9789264239517-en.

51. Bentes M, Dias CM, Sakellarides C, Bankauskaite V. Health care systems in transition. Copenhagen, Denmark: WHO Reg. Off. Eur. behalf Eur. Obs. Heal. Syst; 2004
52. OPSS. Relatório de primavera 2003: saúde que rupturas? Escola Nacional de Saúde Pública, editor. Lisboa: Observatório Português dos Sistemas de Saúde - OPSS; 2003.

53. OPSS. Relatório de primavera 2010: desafios em tempo de crise. Lisboa: Observatório Português dos Sistemas de Saúde - OPSS; 2010.

54. Universidade de Coimbra. Estudo de necessidades previsionais de recursos humanos em saúde médicos: relatório final. Coimbra: Administração Central do Sistema de Saúde - ACSS; 2009

55. Santana P, Couceiro L, Alves I, Nogueira H, Costa C, Santos R. Caracterização demográfica dos profissionais de saúde no serviço nacional de saúde Português. Volume II - B. Profissionais e prestadores no SNS (2002 a 2005). Formação e regime jurídico - Região plano de 1999. Resumo. 2007.

56. Dussault G, Fronteira I. Recursos humanos para a saúde (RHS) plano integrado no plano nacional de saúde 2011-16 (Portugal). Lisboa; Plano Nacional de Saúde 2012-2016, Alto Comissariado da Saúde e Instituto de Higiene e Medicina Tropical; 2010.

57. Lapão LV, Dussault G. From policy to reality: clinical managers' views of the organizational challenges of primary care reform in Portugal. Int J Health Plann Manage England. 2012;27:295-307. doi:10.1002/hpm.2111.

58. Leone C, Dussault G, Lapao LV. Primary health care reform and implications for the organizational culture of Health Center Groups in Portugal. Cad Saude Publica Brazil. 2014;30:149-60. http://dx.doi.org/10.1590/0102$311 \times 00135112$.

59. Diário da República n. ${ }^{\circ} 24$ 1. ${ }^{\text {a }}$ Série - A. Decreto-lei 23/2006. Lisboa: Ministério da Saúde. Diário da República; 2006.

60. Diário da República n. ${ }^{\circ} 161$ 1. ${ }^{a}$ Série. Decreto-lei 298/2007, de 22 de Agosto. Ministério da Saúde. Lisboa: Diário da República; 2007.

61. OPSS. Relatório de primavera 2004: incertezas ... gestão da mudança na saúde. Lisboa, Portugal: Escola Nacional de Saúde Pública; 2004.

62. OPSS. Relatório de primavera 2006: um ano de governação em saúde: sentidos e significados. Coimbra, Portugal: Centro de Estudos e Investigação em Saúde da Universidade de Coimbra; 2006.

63. OPSS. Relatório de primavera 2007: luzes e sombras: a governação da saúde. Coimbra, Portugal: Centro de Estudos e Investigação em Saúde da Universidade de Coimbra; 2007

64. OPSS. Relatório de primavera 2011: da depressão da crise. 2011. Observatório Português dos Sistemas de Saúde - OPSS; 2011.

65. Diário da República n. ${ }^{\circ} 2801$ 1. ${ }^{\text {a }}$ Série - B. Resolução do Conselho de Ministros n. 140/98. Lisboa: Diário da República; 1998. p. 6692-6.

66. Portugal. Plano nacional de saúde 2004-2010: Vol. I_Prioridades. Lisboa, Portugal: Ministério da Saúde. Direcção-Geral da Saúde; 2004.

67. Portugal. Plano nacional de saúde 2012-2016: versão completa. Lisboa: Direç̧ão-Geral da Saúde; 2013.

68. Portugal. Plano Nacional de Saúde 2012-2016: indicadores e metas em saúde. Lisboa: Direcção-Geral da Saúde; 2013.

69. Santana P, Peixoto H, Duarte N. Demography of physicians in Portugal: prospective analysis. Acta Med Port Portugal. 2014;27:246-51.

70. Grupo de Trabalho de Educação Médica, Associação Nacional de Estudantes de Medicina. Campanha nacional educação médica: a evolução do número de estudantes e das condições pedagógicas das escolas médicas portuguesas. 2011.

71. Ordem dos Médicos. Especialidades. Ordem dos Médicos. 2009. Available from: https://www.ordemdosmedicos.pt/?lop=conteudo\&op= 02522a2b2726fb0a03bb19f2d8d9524d [last accessed in Apr 2016].

72. Portugal. SNS serviço nacional de saúde: ACSS administração central do sistema de saúde, IP: departamentos e unidades: departamento gestão e planeamento RH: internato médico [Internet]. Adm. Cent. do Sist. Saúde. 2016. Available from: http://www.acss.min-saude.pt/DepartamentoseUnidades/ DepartamentoGest\%C3\%A3oePlaneamentoRH/InternatoM\%C3\%A9dico/tabid/ 1231/language/pt-PT/Default.aspx [last accessed in May 2016].

73. Portugal. Portal da saúde: medidas do governo promovem trabalho médico no SNS: 0903 15. Ministério da Saúde, Serviço Nac. Saúde. 2015.

74. Diário da República n. ${ }^{\circ} 73$ 1. ${ }^{a}$ Série. Decreto-Lei n. ${ }^{\circ}$ 53/2015. Ministério da Saúde. 2015;1881-2.

75. OPSS. Relatório de primavera 2009: 10/30 anos: razões para continuar. Observatório Português dos Sistemas de Saúde - OPSS; 2009.

76. Diário da República I Série B № 226. Decreto-Lei N. ${ }^{\circ}$ 580/76. Ministério dos Assuntos Sociais. 1976;1627.

77. Diário da República n. 31 1. ${ }^{\text {a }}$ Série. Decreto-Lei n. ${ }^{\circ}$ 45/2009. Lisboa: Ministério da Saúde; 2009. p. 1051-62. 
78. Diário da República n. ${ }^{\circ} 61$ 2. Série. Despacho n. ${ }^{\circ}$ 6474/2005. Lisboa: Ministério da Saúde. Diário da República; 2005.

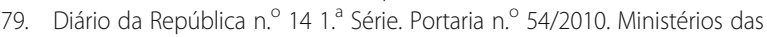
Finanças e da Adm. Pública e da Saúde. Lisboa: Diário da República; 2010. p. 212-6.

80. Diário da República n. ${ }^{\circ} 48$ 1. ${ }^{a}$ Série. Portaria n. ${ }^{\circ}$ 70/2015. Ministérios das Finanças e da Saúde. Lisboa: Diário da República; 2015. p. 1497-8.

81. Masantet E, Hernández Plaza S, Padilla B. A competência cultural dos(as) médicos(as) latino- americanos(as) na prestação de cuidados de saúde em Portugal: algumas notas preliminares. Immigr Matern - Iberoam J Heal Citizsh - Rev Iberoam. Salud y Ciudad. 2012;:16-18.

82. Público. A opção sul-americana. Público. 2011; Available from: http://www. publico.pt/portugal/jornal/a-opcao-sulamericana-23129381. Accessed May 2016.

83. Público. Médicos colombianos nos centros de saúde dão resposta a 70 mil. Público. 2011; Available from: http://www.publico.pt/portugal/jornal// medicos-colombianos-nos-centros-de-saude-dao-resposta-a-70-mil21864716. Accessed May 2016.

84. Correio da Manhã. Cem colombianos vêm dar consultas. Corr. da Manhã. 2011. Available from: http://www.cmjornal.pt/sociedade/detalhe/cemcolombianos-vem-dar-consultas. Accessed May 2016.

85. Público. Chegaram mais 40 médicos colombianos e estrangeiros são quase 10\% do total nacional. Público [Internet]. 2011. Available from: http://www. publico.pt/portugal/jornal/chegaram-mais-40-medicos-colombianos-eestrangeiros-sao-quase-10-do-total-nacional-22086051. Accessed May 2016

86. Público. Ministério contrata 44 médicos cubanos para centros de saúde do Alentejo, Algarve e Lisboa. Público. 2009. Available from: https://www.publico. $\mathrm{pt} /$ sociedade/noticia/ministerio-contrata-44-medicos-cubanos-para-centros-desaude-do-alentejo-algarve-e-lisboa-1397113 [last accessed in May 2016].

87. Público. Dúvidas sobre capacidade profissional dos clínicos. Público. 2009. Available from: http://www.publico.pt/portugal/jornal/duvidas-sobrecapacidade-profissional-dos-clinicos-17951366 [last accessed in May 2016].

88. Jornal de Notícias. Ministério contratou 44 médicos cubanos para o Algarve e Alentejo. J. Notícias. 19/04/2015; 2009.

89. Público. Nova vaga de médicos de Cuba a caminho de Portugal. Público. 2012. Available from: http://www.publico.pt/portugal/jornal/nova-vaga-de-medicosde-cuba-a-caminho-de-portugal-23952364 [last accessed in May 2016]

90. Correio da Manhã. Mais médicos no Alentejo. Corr. da Manhã. 2012. Available from: http://www.cmjornal.pt/sociedade/detalhe/mais-medicosno-alentejo . Accessed July 2016

91. Público. Médicos cubanos já terão custado 12 milhões de euros ao Estado. Público. 2014. Available from: https://www.publico.pt/sociedade/noticia/ medicos-cubanos-ja-terao-custado-12-milhoes-de-euros-1666908 [last accessed in May 2016].

92. Correio da Manhã. Aberto concurso para 250 médicos de família. Corr. da Manhã. 2014. Available from: http://www.cmjornal.pt/sociedade/detalhe/ aberto-concurso-para-250-medicos-de-familia . Accessed May 2016.

93. Correio da Manhã. Ordem acolhe médicos cubanos. Corr. da Manhã. 2014. Available from: http://www.cmjornal.pt/sociedade/detalhe/ordem_acolhe_ medicos_cubanos. Accessed May 2016.

94. Correio da Manhã. Mais 40 médicos colombianos em Portugal. Corr. da Manhã. 2011. Available from: http://www.cmjornal.pt/sociedade/detalhe/ mais-40-medicos-colombianos-em-portugal. Accessed May 2016.

95. Jornal de Notícias. Utentes dizem que Ordem deve "aligeirar" burocracia para que médicos da Costa Rica exerçam. J. Notícias. 2011. Available from: http://www.jn.pt/sociedade/interior/utentes-dizem-que-ordem-devealigeirar-burocracia-para-que-medicos-da-costa-rica-exercam-2033917.html Accessed May 2016

96. Jornal de Notícias. Bastonário responsabiliza governos de Portugal e Costa Rica pela situação dos médicos. J. Notícias. 2011. Available from: http:// www.jn.pt/sociedade/interior/bastonario-responsabiliza-governos-deportugal-e-costa-rica-pela-situacao-dos-medicos-2033878.html . Accessed May 2016.

97. Público. Médicos costa-riquenhos estão há quatro meses a receber sem trabalhar. Público. 2011. Available from: https://www.publico.pt/sociedade/ noticia/medicos-da-costa-rica-em-portugal-nao-trabalham-porresponsabilidade-dos-dois-governos-1514993 [last accessed in May 2016].

98. Correio da Manhã. Algarve: 18 médicos cubanos reforçam serviços. Corr. da Manhã. 2009. Available from: http://www.cmjornal.pt/sociedade/detalhe/ algarve-18-medicos-cubanos-reforcam-servicos . Accessed May 2016.
99. Público. Cem médicos uruguaios contratados para as VMER. Público. 2007. Available from: http://www.publico.pt/portugal/jornal/cem-medicosuruguaios-contratados-para-as-vmer-224987. Accessed May 2016.

100. Correio da Manhã. Médicos de Cuba com desconto. Corr. da Manhã. 2012. Available from: http://www.cmjornal.pt/sociedade/detalhe/medicos-decuba-com-desconto . Accessed May 2016.

101. Diário da República n. 218 2. ${ }^{a}$ Série. Despacho n. ${ }^{\circ} 23$ 095/2006. Ministério da Saúde. Lisboa: Diário da República; 2006. p. 25217.

102. Portugal. Actuais e futuras necessidades previsionais de médicos (SNS). Administração Central do Sistema de Saúde - ACSS, 2011.

103. Portugal. Aposentações no ministério da saúde ano 2007 e evolução desde 1998. Lisboa: Administração Central do Sistema de Saúde - ACSS; 2009.

104. Portugal. Publicação periódica sobre o número de utentes inscritos nos cuidados de saúde primários. Lisboa, Portugal; 2015. Available from: http://www2.acss.min-saude.pt/Portals/0/Rel_CSP_Julho_21082015.pdf Accessed May 2016.

105. WHO. How to conduct a discrete choice experiment for health workforce recruitment and retention in remote and rural areas: a user guide with case studies. 2012. p. 1-94.

106. Dal Poz MR. The health workforce crisis. Cad Saude Publica. 2013;29:1924-6. http://dx.doi.org/10.1590/0102-311XPE011013.

107. Pollard A, Court J. How civil society organisations use evidence to influence policy processes: a literature review. London; 2005. Report No.: 249.

108. Lasswell HD. The Politics of Prevention. In: Psychopathol. Polit. Chicago: University of Chicago Press and University Chicago Press, Ltd., London; 1977.

109. Fischer F, Miller GJ, Sidney MS, editors. Handbook of public policy analysis: theory, politics, and method. Boca Raton: Taylor \& Francis Group, LLC; 2007.

110. Walt G, Shiffman J, Schneider H, Murray SF, Brugha R, Gilson L. "Doing" health policy analysis: methodological and conceptual reflections and challenges. Health Policy Plan. 2008:23:308-17. doi:10.1093/heapol/czn024.

111. NCCHPP. Understanding policy developments and choices through the "3-i" framework: interests, ideas and institutions. 2014. Available from: http:// www.ncchpp.ca/165/Publications.ccnpps?id_article $=1077$ [last accessed in Jul 2016].

112. Lavis JN, Ross SE, Hurley JE, Hohenadel JM, Stoddart GL, Woodward CA, et al. Examining the role of health services research in public policymaking Milbank Q. 2002:80:125-54.

113. Hanney SR, Gonzalez-Block MA, Buxton MJ, Kogan M. The utilisation of health research in policy-making: concepts, examples and methods of assessment. Heal Res Policy Syst. 2003;1:2.

114. Lavis JN. Research, public policymaking, and knowledge-translation processes: Canadian efforts to build bridges. J Contin Educ Health Prof. 2006;26:37-45. doi:10.1002/chp.49.

115. Portugal. Serviço Nacional de Saúde. 2016.

116. Portugal. SNS: serviço nacional de saúde. Ministério da Saúde, Serviço Nac. Saúde. 2016. Available from: www.sns.gov.pt [last accessed in May 2016].

117. Portugal. DGS: direção-geral da saúde: desde 1899: melhor informação mais saúde. Serviço Nac. Saúde. 2011. Available from: https:/wwww.dgs.pt/ [last accessed in May 2016].

118. Portugal. Plano nacional de saúde. Available from: http://pns.dgs.pt [last accessed in Jul 2016].

119. Ordem dos Médicos. Ordem dos Médicos. 2009. Available from: https:// www.ordemdosmedicos.pt/. Accessed May 2016.

120. Universidade de Coimbra. OPSS: observatório português dos sistema de saúde. Univ. Coimbra. 2014.

121. WHO. World Health Organization. 2016. Available from: http://www.who.int/en/ Accessed July 2016.

122. OECD. OECD: better policies for better lives. Organ. Econ. Co-operation Dev. 2016. Available from: http://www.oecd.org/ . Accessed July 2016].

123. Barer ML, Wood L. Common problems, different "solutions": learning from international approaches to improving medical services access for underserved populations. Vancouver, BC: The Univerity of British Columbia, Centre for Health Services and Policy Research, Health Human Resources Unit Research Reports; 1997. p. 30. 